\title{
Analysis of intact ladderane phospholipids, originating from viable anammox bacteria, using RP-LC-ESI-MS
}

\author{
Ingela Lanekoff • Roger Karlsson
}

Received: 4 April 2010 /Revised: 3 June 2010 / Accepted: 8 June 2010 / Published online: 17 June 2010

(C) The Author(s) 2010. This article is published with open access at Springerlink.com

\begin{abstract}
Since the discovery of the anaerobic ammonium oxidizing (anammox) bacteria, many attempts have been made in order to identify these environmentally important bacteria in natural environments. Anammox bacteria contain a unique class of lipids, called ladderane lipids and here we present a novel method to detect viable anammox bacteria in sediments and waste water treatment plants based on the use of a ladderane lipid biomarker. Intact ladderane phosphatidylcholine (PC) lipids are analyzed using reversed-phase liquid chromatographyelectrospray ionization-mass spectrometry. Following extraction from the complex sediment matrix, reversedphase LC is used to separate ladderane PC lipids based on their tail group hydrophobicity as well as their ether or ester link to the glycerol backbone in the sn-2 position. We investigate the presence of intact ladderane lipids in natural sediments displaying anammox activity and illustrate the use of a specific intact membrane forming PC lipid as a biomarker for viable anammox bacterial cells. The presented method can be used to elucidate the whereabouts of viable anammox bacteria, subsequently enabling an estimation of anammox activity. This will greatly increase the knowledge of anammox bacteria and their importance in the global nitrogen cycle.
\end{abstract}

Keywords Ladderane lipids · LCMS · Biomarker .

Anammox bacteria $\cdot$ Nitrogen cycle

I. Lanekoff $\cdot$ R. Karlsson $(\bowtie)$

Department of Chemistry, University of Gothenburg,

Kemivagen 10,

41296 Gothenburg, Sweden

e-mail: rogerk@chem.gu.se

\section{Introduction}

It is estimated that $25 \%$ to $50 \%$ of the total global marine nitrogen gas $\left(\mathrm{N}_{2}\right)$ production proceeds via the anaerobic ammonium oxidation (anammox) reaction [1, 2]. Locally, the anammox contribution might be even higher [2]. Bacteria performing anammox were discovered in the 1990s in a waste water reactor and have since been found in a multitude of environments [3-7]. Anammox bacteria convert biologically available nitrogen species like ammonia, nitrate and nitrite into $\mathrm{N}_{2}$, which is returned to the atmosphere. In this sense they are crucial for sustaining the nitrogen balance in our environment [8] and great efforts have been made in the search for evidence of their presence and activity in natural environments.

${ }^{15} \mathrm{~N}$-tracer studies have been used to determine rates of anammox by measuring the formation of ${ }^{29} \mathrm{~N}_{2}$ following incubation of ${ }^{15} \mathrm{~N}$-labeled nitrate [9, 10]. Together with predictions from nutrient and oxygen profiles, this method has been very useful in elucidating where the anammox reaction takes place [11-16]. However, studies using ${ }^{15} \mathrm{~N}$-labels cannot alone be used to state whether the anammox bacteria are involved or not since the anammox reaction also can take place through alternative routes [17]. Using 16SrRNA gene analysis and molecular techniques such as fluorescence in situ hybridization (FISH) and quantitative polymerase chain reaction (qPCR), anammox bacteria have been found both in sediments and water pillars [7, 11, 13, 18, 19]. Furthermore, FISH has been a successful methodology not only for determining the presence but also the diversity of anammox bacteria species. However, FISH is a method that relies on fluorescence measurements thus making quantitative measurements problematic since mineral and organic particles tend to quench the fluorescence signal when sediment 
samples are analyzed. The quantitative determination of anammox bacterial abundance through qPCR is also associated with issues. Observations have shown that both RNA and DNA can be relatively stable after cell lysis $[20,21]$ resulting in enhanced signals due to fossil RNA and DNA $[22,23]$. Hence, this technique might not reflect the actual amount of viable anammox bacteria.

Our approach is to determine the presence of anammox bacteria by using a specific intact membrane forming phosphatidylcholine lipid from the family of so-called ladderane lipids as a biomarker for these bacteria in sediment $[2,3,6,7,13,24]$. Of all bacterial cells examined to date, ladderane lipids have only been found in anammox bacteria [25]. Ladderane lipids contain linearly concatenated cyclobutane structures at the end of the hydrocarbon tails, forming a ladder-like structure (Fig. 1). These highly strained structures are found as phosphatidylcholine (PC), phosphatidylethanolamine (PE), and phosphatidylglycerol (PG) lipids as well as fatty acids (FA) and lysophospholipids [26-28]. The intact ladderane lipids exist predominantly with an ether linkage to the sn-2 position of a glycerol back bone, via an alkyl chain, while the sn-1 position is linked via either an ether or ester bond [26, 29]. Capillary gas chromatography (GC) mass spectrometry (MS) has been used to analyze ladderane phospholipids as ladderane FAMEs (fatty acid methyl esters) after derivatization [30]. However, the chromatograms obtained suffered from very broad peaks, containing several small peaks with almost identical mass spectra. This suggested that the strained cyclobutane structure of the ladderane FA was thermally unstable and degraded during GC analysis [30, 31]. An improved method for the analysis of ladderane FAs based on normal-phase high-performance liquid chromatography (NP-HPLC)atmospheric pressure chemical ionization tandem mass spectrometry (APCI-MS/MS) was later developed [32], as well as a method for the analysis of a ladderane monoether PC lysolipid [33]. However, as these techniques rely on the analysis of FAs and lysophospholipids they have not provided a direct link to the amount of living anammox bacteria. In 2009, Jaeschke et al. [33] showed that the C20-[3]-ladderane monoether PC, a lysophospholipid retaining an intact PC head group but having only one alkyl chain, was a better biomarker for viable anammox bacteria than the ladderane FAs. However, lysophospholipids as well as FAs are only present in very low amounts in living cells since the majority of the membrane is constituted of intact lipids containing two non-polar hydrocarbon tail groups linked to a polar headgroup. During degradation, the intact membrane forming phospholipids readily lose their headgroup but also one of the alkyl chains, especially if it is linked to the glycerol backbone via an ester bond, resulting in fatty acids and lysophospholipids as degradation products. In several articles, it has been shown that intact membrane forming phospholipids is a reliable tool for detecting viable bacteria in sediments [34-40], due to the rapid decomposition of phospholipids after cell death. Earlier work performed by Boumann et al. [26] has demonstrated the separation and detection of intact ladderane lipids extracted from bacterial cell cultures and waste water treatment plants, using normalphase LC and MS detection. The method separates intact phospholipids into PC, PE and PG species, but it does not allow for separation of the lipids based on their tail groups or bond to the glycerol backbone. Earlier studies indicate that there are many different types of ladderane lipid species, due to a wide range of hydrocarbon chains bonded to the glycerol backbone either via an ether or ester bond in the sn-1 position. When a specific intact lipid is to be used as a biomarker for viable anammox bacteria, it is of utmost importance that the method of use separates the lipids into individual ladderane lipid species. Using normal-phase LC separation, however, it is impossible to distinguish between individual species having different tail groups but sharing the same head group. The method by Boumann et al. [26] has not been used for analyzing intact membrane forming ladderane lipids from anammox bacteria in sediment samples. The analysis of lipids originating from sediments is complicated by the presence of many different phospholipid species as well as a much higher amount of contaminating organic material as compared to waste water treatment samples. This puts high demands on the LC method to separate out specific individual phospholipids to be used as biomarkers in sediment samples. Here, we have developed a method using a specific intact membrane forming ladderane PC lipid $(\mathrm{m} / \mathrm{z}$ 816, Fig. $1 \mathrm{IV})$ as a biomarker for viable anammox bacterial cells in natural sediments displaying anammox activity. The method enables PC lipids to be separated based on their tailgroup hydrophobicity as well as their attachment to the glycerol back bone, which can be either through an ether-ether or ester-ether bond. This enables analysis of specific ladderane PC lipids in anammox bacteria from natural ocean sediments. Here we show that the presence of the specific ladderane PC lipid at different depths in a sediment core correlates well with established nutrient and oxygen profiles in sediments as well as profiles of anammox bacterial abundance estimated using molecular techniques including FISH and qPCR [33].

\section{Experimental section}

\section{Chemicals}

Phospholipid reference samples 1,2-didecanoyl-sn-glycero-3phosphocholine (10PC), 1,2-dipalmitoyl-sn-glycero-3-phosphocholine (16PC), 1,2-diphytanoyl-sn-glycero-3-phosphocholine (4Me 16PC), 1,2-di-O-hexadecyl-sn-glycero-3-phosphocholine 

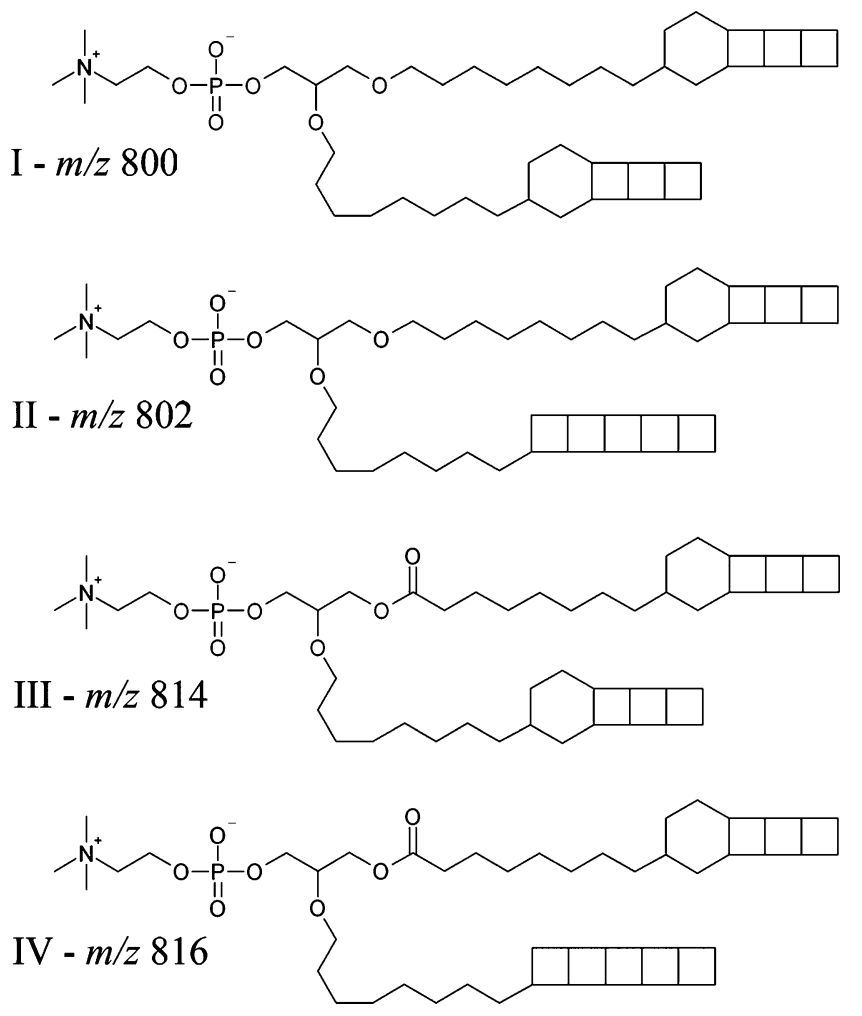

Fig. 1 Schematic illustrations of ladderane PC lipids investigated in this study. (I) Diether lipid at $m / z$ 800, (II) diether lipid at $\mathrm{m} / \mathrm{z} 802$, (III) ether/ester lipid at $m / z$ 814, (IV) ether/ester lipid at $m / z$ 816. Note the sequentially linked cyclobutane/cyclohexane structures at the end of the hydrocarbon tails

(DE 16PC), and 1,2-distearoyl-D70-sn-glycero-3-phosphocholine (D70 18PC) were from Avanti Polar Lipids. For LCMS measurements LCMS grade methanol $(\mathrm{MeOH})$ and 2-propanol (isopropyl alcohol, IPA) were from Riedel-de Haën, formic acid from Fluka and ammonia from Merck. Sodium (meta) periodate, chloroform, $n$-hexane, ammonium bicarbonate, and diethylether were from Sigma-Aldrich. Dichloromethane (DCM) and dichlorodimethylsilane were from Fluka and $\mathrm{NH} 2$ solid-phase extraction (SPE) columns (500 mg, $3 \mathrm{~mL}$ ) from Strata.

\section{Materials}

For method development, anammox bacteria growing in biofilms on plastic biofilm carriers (Anoxkaldnes AB, Lund, Sweden) were obtained from Himmerfjärdsverkets waste water treatment plant in Stockholm, Sweden. Ladderane PC lipids extracted from anammox bacteria biofilms were used as references to determine the $\mathrm{LC}$ retention time during sediment analysis. Sediment core samples (divided into depths $0-3$, 3-6, 6-9, and 9-12 cm) were obtained from Gullmarsfjorden outside Lysekil on the west coast of Sweden and stored at $4{ }^{\circ} \mathrm{C}$ for a few days until analysis was performed.

\section{Biofilm extraction}

To extract ladderane lipids, three different protocols were investigated. The first protocol is described by Zink and Mangelsdorf [41] where MeOH:DCM:10 mM ammonium acetate $(\mathrm{AmAc})$ is used in the ratio of 2:1:0.8. The second follows the Folch procedure using a mixture of chloroform: $\mathrm{MeOH}(2: 1)$ [42] and the third, from Hara et al. [43], uses a mixture based on $n$-hexane:isopropanol (3:2). Prior to extraction the biofilm samples were centrifuged and carefully weighed to ensure that a comparison between the differently treated biofilm samples could be made. In all methods we used ultrasonication, as described below, and extracted the lipids three times with a centrifugation step in between. Supernatants were combined and collected in separate separation funnels.

All biofilm samples were subjected to liquid-liquid extraction (LLE), as described in the original papers [41-43], and SPE [44]. The phospholipid fractions were fully evaporated in a silanized test tube under a stream of nitrogen gas, re-dissolved in $200 \mu \mathrm{L}$ mobile phase, and stored for a short period of time under nitrogen atmosphere at $-80{ }^{\circ} \mathrm{C}$ prior to LCMS analysis. The Folch [42] and Hara [43] procedures were less efficient than the Zink procedure [41] and were thus not used for the sediment extractions.

\section{Sediment incubation and extraction}

A sediment core was obtained from Gullmarsfjorden ( $\sim 110 \mathrm{~m}$ below sea surface) and divided into four $3-\mathrm{cm}$ thick samples between 0 and $12 \mathrm{~cm}$ of depth. An aqueous solution containing 5\% sodium (meta) periodate $(150 \mathrm{ml})$ was added to $150 \mathrm{~g}$ of wet sediment. The sediment slurry was sonicated for $2 \mathrm{~min}$, using an ultrasonic processor (Sonics Vibracell, Model 501) at 70\%, with a 7 -s pulse and a 5-s rest. The slurry was incubated at $4{ }^{\circ} \mathrm{C}$ for a period of 1-week to break clusters of bacteria and to lyse cells $[45,46]$. After incubation, the sample was transferred to two $250-\mathrm{mL}$ centrifuge flasks (Teflon FEP, Nalgene) and centrifuged at 3,220 g for $15 \mathrm{~min}$ using an Eppendorf Centrifuge 5810R. The supernatants were combined and collected in a separation funnel.

$\mathrm{MeOH}(75 \mathrm{ml})$ was added to each centrifuge flask and the sample was sonicated and centrifuged using the same conditions as above. The $\mathrm{MeOH}$ supernatants were also combined and collected in a separate separation funnel.

To further extract lipids, the Zink procedure [41] was used. The sample was again treated with ultrasonication as described above but with $75 \mathrm{~mL}$ of $\mathrm{MeOH}$ : DCM: AmAc $(2: 1: 0.8)$ three times per flask with centrifugation steps in between [41]. The supernatants were combined and collected in separate separation funnels. 
Sediment sample clean up procedure

Prior to LLE, DCM, and AmAc were added to all the separation funnels until the ratios of the solvents were MeOH: DCM: AmAc 1:1:0.9. After phase separation, the DCM phases were collected in a round bottom flask. The water phase was subjected to two more extractions where DCM: $\mathrm{MeOH}$ was added in a ratio of 2:1 [41]. Again, the DCM phases were collected and combined with the previous extracts. The DCM in the round bottom flask was reduced using a rotavaporator from Büchi, and fully evaporated in a silanized test tube under a flow of nitrogen gas. The sample was re-dissolved in $12 \mathrm{~mL}$ of $2: 1$ $n$-hexane:chloroform and stored under nitrogen atmosphere at $-80{ }^{\circ} \mathrm{C}$ until subjected to further clean up by SPE. Four SPE columns (Strata NH2 $(55 \mu \mathrm{m}, 70 \mathrm{~A})$ $500 \mathrm{mg}, 3 \mathrm{~mL}$ ) per sample were connected to a vacuum box (Resprep vacuum manifold with 12 ports) and activated with $12 \mathrm{~mL} \mathrm{MeOH}$. The columns were conditioned with $12 \mathrm{~mL}$ of $n$-hexane prior to loading the sample. A wash with $12 \mathrm{~mL}$ chloroform:IPA (2:1) eluted cholesterylesters, triglycerides, cholesterols, diglycerides, and monoglycerides. FAs were eluted with $2 \%$ acetic acid in diethylether. Finally, the phospholipids were eluted with $12 \mathrm{~mL}$ of $\mathrm{MeOH}$, combined and fully evaporated in a silanized test tube under a stream of nitrogen gas [44]. The clean sample was re-dissolved in $200 \mu \mathrm{L}$ mobile phase, and stored under nitrogen atmosphere for a short period of time at $-80{ }^{\circ} \mathrm{C}$ prior to LCMS analysis.

\section{Liquid chromatography and mass spectrometry}

Separation was achieved using a Gemini C18 column $(50 \times 2 \mathrm{~mm}, 3 \mu \mathrm{m}$ particle diameter, hybrid silica gel column for reversed-phase HPLC) with a Gemini C18 guard column $(4 \times 2 \mathrm{~mm})$, from Phenomenex. The temperature of the column was kept constant at $30{ }^{\circ} \mathrm{C}$ using a column oven LCO 102 from Ecom. The mobile phases in the gradient consisted of $\mathrm{A} ; 4 \%$ water, $0.1 \%$ formic acid, and $0.1 \%$ ammonia $(25 \%)$ in $\mathrm{MeOH}$ and $\mathrm{B}$; isopropanol (IPA) containing $0.1 \%$ formic acid and $0.1 \%$ ammonia (25\%). The initial composition with a flow of $0.4 \mathrm{~mL} / \mathrm{min}$ was $100 \%$ A which was lowered to $70 \%$ A between 10 and $20 \mathrm{~min}$ of the separation. At $21 \mathrm{~min}$, the flow was lowered to $0.2 \mathrm{~mL} / \mathrm{min}$ and $100 \% \mathrm{~B}$ was used to wash the column for $10 \mathrm{~min}$ before returning to the initial conditions. Total analysis time, including washing step, for each sample was $40 \mathrm{~min}$. The analytes were eluted within $20 \mathrm{~min}$.

Analysis of biofilm samples during method development was performed using a 600S Controller and 626 Pump from Waters and a 234 autosampler from Gilson coupled to a Micromass Quattro LC, triple quadrupole, with electrospray ionization (ESI). MS/MS analysis enabled parental ion scanning of the PC headgroup, at $\mathrm{m} / \mathrm{z} 184$, to detect PC lipids. Argon was used as collision gas, the potential over the capillary was $4.0 \mathrm{kV}$ and the cone voltage was $90 \mathrm{~V}$. Source block temperature was held at $150{ }^{\circ} \mathrm{C}$ and desolvation temperature at $300{ }^{\circ} \mathrm{C}$.

Sediment sample analysis was performed using a PerkinElmer Series 200 autosampler and LC pump coupled to a Micromass QToF, quadrupole time-of-flight with ESI scanning between $m / z 100$ and 900 . As a retention time reference for ladderane PC lipids a biofilm sample extract was consecutively analyzed using the QToF set-up.

\section{Results and discussion}

Ladderane PC lipid extraction and sample clean up

Anammox bacteria have been shown to form biofilms when cultured in waste water reactors and most likely grow in clusters in ocean sediments as well. Biofilm and clusters are mostly formed via a protein-polysaccharide matrix [47, 48] and biofilm formation makes it more difficult to lyse cells in order to extract lipids from the cell membranes. For this study, several chemical and physical treatments, including boiling, hydrogen peroxide or hypochlorate treatments, mechanical homogenization and sonication were attempted in order to separate and lyse cells in biofilms (data not shown). The success of these treatments were monitored using fluorescence microscopy by staining the cells with 4',6-diamidino-2-phenylindole. Furthermore, the extracted ladderane PC lipids were analyzed using LCMS post extraction. The best results, showed by lack of ladderane lipids in samples extracted a second time, were achieved when anammox bacteria in biofilms were incubated with a $5 \%$ solution of periodate prior to probe sonication, as described in the experimental section $[45,46]$. No significant difference in the ladderane PC lipid composition or quantity depending on the periodate incubation time ( 2 days versus 7 days) were observed, showing that no decomposition of the ladderane PC lipid occurred during incubation (data not shown).

In ocean sediments from Gullmarsfjorden, approximately $3 \%$ of all bacteria have been found to be anammox bacteria [4]. The low cell abundance and the complexity of the sediment sample matrix puts high demands on the extraction method. To optimize the yield of ladderane PC lipids in the extraction step, we compared three extraction protocols, using carefully weighed triple samples of anammox bacteria in biofilms. The solvent mixtures in the compared methods were; chloroform: $\mathrm{MeOH}$ [42], $n$-hexane:isopropanol [43] and $\mathrm{MeOH}: \mathrm{DCM}: \mathrm{AmAc}$ [41]. After extraction and sample cleanup, all samples were analyzed using the described LCMS method. In Fig. 2, the area of the integrated peaks of 


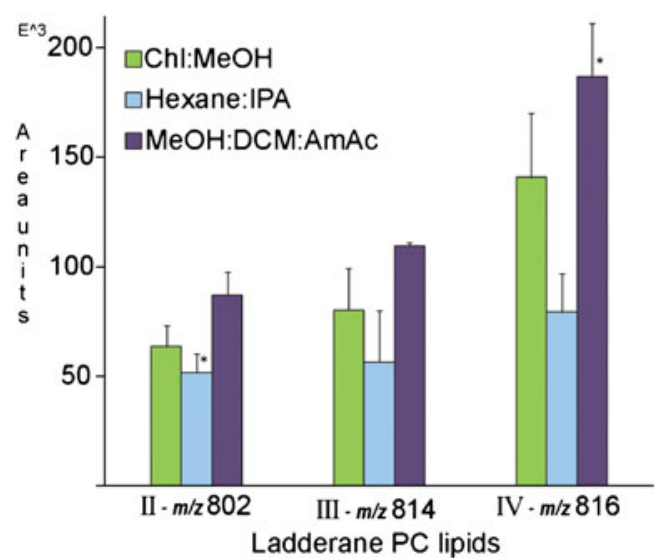

Fig. 2 Comparison of three extraction methods for ladderane PC lipids found at $m / z 802(I I), 814(I I I)$, and $816(I V), n=3$. The Roman numerals $I I, I I I$, and $I V$ denote the structures illustrated in Fig. 1. $*$ Denotes a significant difference (students $t$ test $<0.05$ )

three chosen ladderane PC lipids, found at $\mathrm{m} / \mathrm{z} 802,814$, and 816 , are compared. The result shows that the highest yield of ladderane PC lipids is obtained when the mixture of $\mathrm{MeOH}$ : DCM:AmAc [41] is used.

\section{LC method for ladderane lipids}

The developed reversed-phase LC method separates PC lipids based on the tail group hydrophobicity, making the ladderane lipids elute last. Figure $3 \mathrm{~b}$ shows the chromatogram generated during separation of the five non-ladderane PC lipid standards shown in Fig. 3a. This confirms that the LC method separates the PC lipids based on the length and hydrophobicity of the hydrocarbon tail group. Furthermore, the method separates the PC lipids based on the link to the glycerol bond, where the more polar ether-ester-linked lipids elute before the ether-ether linked lipids with the same tail groups. This feature of the separation is especially important when a specific ladderane lipid is being used as a biomarker.

The concentrations of all lipids in Fig. $3 \mathrm{~b}$ are the same, but the response varies considerably. The most obvious difference is that the response of the ether-ether lipid is several magnitudes lower. This decreased signal intensity could be due to the lower ionization or fragmentation

Fig. 3 Chromatograms showing the LC separation of ladderane PC lipids. a Structures of five non-ladderane $\mathrm{PC}$ lipids used during method development. (1) 10PC, (2) 16PC, (3) DE 16PC, (4) D70 18PC, (5) $4 \mathrm{Me} 16 \mathrm{PC}$. b Chromatogram of the non-ladderane PC standards at the same concentration analyzed by RP-LC QqQ using parental ion scanning of $\mathrm{m} / \mathrm{z}$ 184. c Chromatogram of a biofilm sample containing anammox bacteria analyzed by RP-LC QqQ using parental ion scanning of $m / z$ 184. Ladderane lipids elute last in the chromatogram. The more polar ether-ester-linked ladderane PC lipids $I I I$ and $I V$ elute before the ether-ether linked $I$ and $I I$ efficiency of the diether PC during mass spectrometric analysis [49]. The higher detection limit of diether species encouraged the use of a non diether specie as biomarker. In Fig. 3c, a biofilm sample containing anammox bacteria is analyzed using parental ion scanning of the PC headgroup.

a

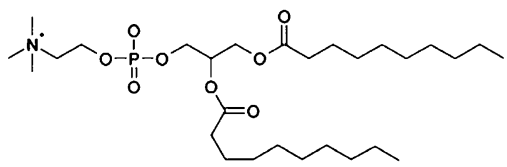

2

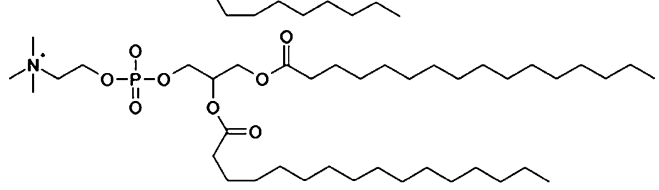

3

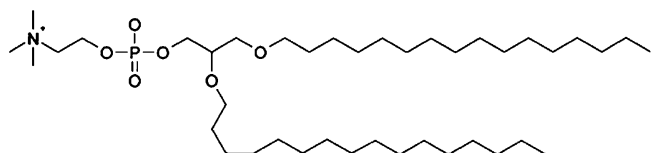

4

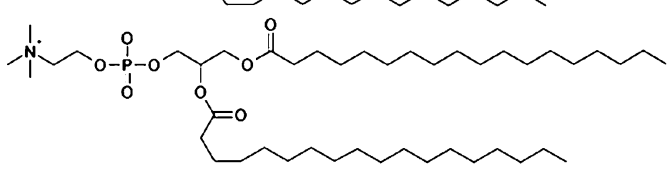

5
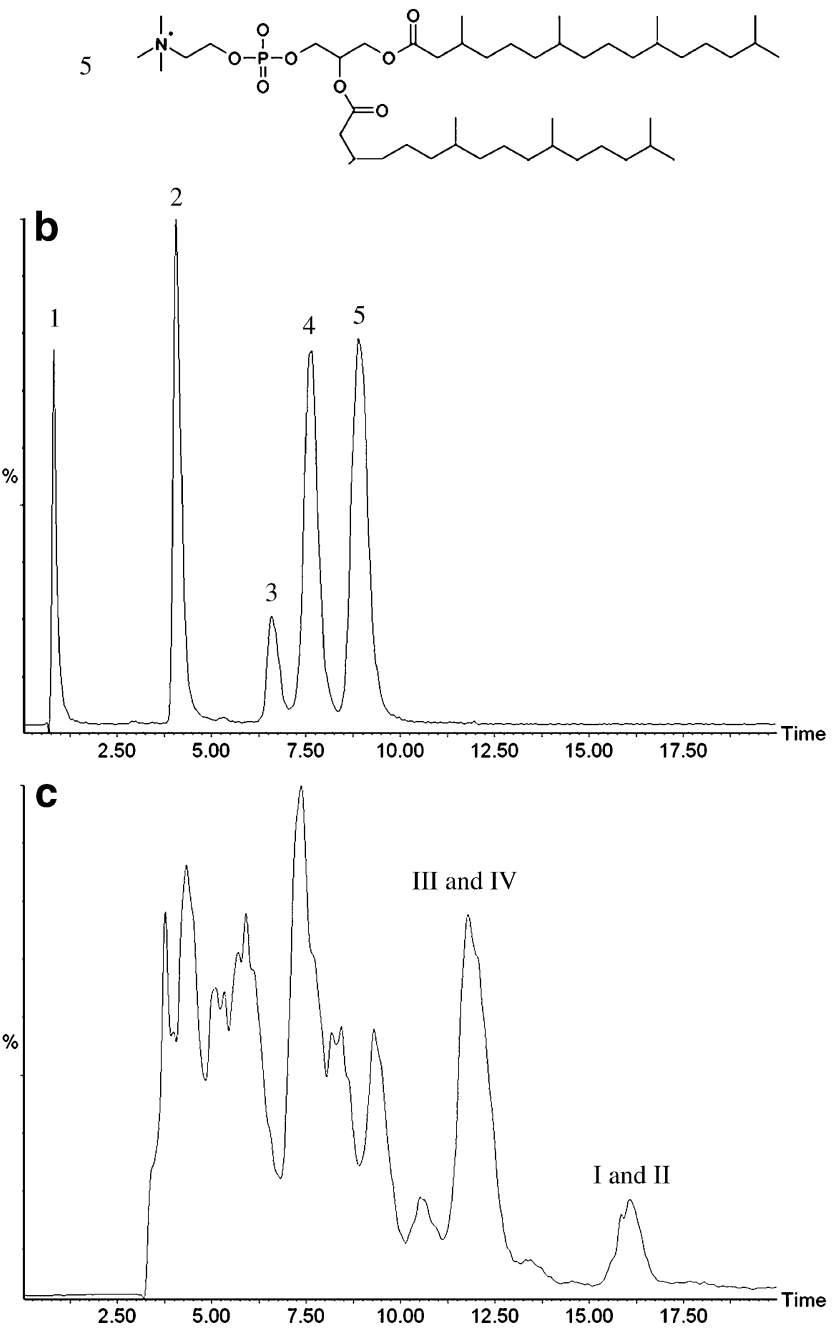
The almost identical ladderane PC lipids at $\mathrm{m} / z \quad 814$ (III) and $\mathrm{m} / \mathrm{z} 816$ (IV), both being ester-ether ladderane PC lipids, coelute in the peak denoted by III, IV in Fig. 3c. As expected, the ladderane PC lipids at $\mathrm{m} / z 800$ (I) and $\mathrm{m} / \mathrm{z} 802$ (II), also almost identical but both diether ladderane PC lipids, coelute later in the peak denoted by I, II. The coelution of species III and IV as well as I and II is acceptable since these analytes originate from the anammox bacteria in constant relative concentrations, thus keeping an eventual discrimination effect during analysis constant.

Mass spectrometry of ladderane lipids

For electrospray mass spectrometry, PC lipids ionize best in the positive ion mode and readily lose their headgroup at $\mathrm{m} / \mathrm{z} 184$ when subjected to collision induced dissociation. A QqQ, using parental ion scanning of the $m / z 184$ fragment ion, was used for analyte confirmation during method development. Figure $4 \mathrm{a}$ shows the chromatogram of an anammox biofilm sample. The two peaks eluting last contain the intact ladderane PC lipids I-IV as shown in the corresponding mass spectra (Fig. 4b-c). The detection limits of the ladderane PC lipids was found to be higher when using parental ion scanning on the QqQ compared to scanning using the QToF. This can partly be explained by the fact that the ladderane PC lipids have comparably long hydrocarbon tail groups which make them hard to fragment [46]. Therefore, we used the QToF, scanning between $\mathrm{m} / \mathrm{z}$ 100 and 900, to detect ladderane PC lipids in sediment samples which contain substantially lower amounts than biofilm samples. In Fig. 4d, a sediment sample is analyzed by RP-LC QToF and the selected mass chromatogram, i.e. a chromatogram where the $\mathrm{m} / \mathrm{z} 816$, corresponding to the ladderane PC lipid IV, is extracted out of the total ion chromatogram, is shown. The peak labeled as IV is the ladderane PC lipid at $m / z 816$ and the corresponding mass spectrum of that peak is found in Fig. 4e. This clearly shows the presence of anammox bacteria in the ocean sediment sample that was taken from Gullmarsfjorden on

Fig. 4 Chromatograms and mass spectra of intact ladderane PC lipids. a Chromatogram of a biofilm sample containing anammox bacteria analyzed by RP-LC QqQ using parental ion scanning of $\mathrm{m} / \mathrm{z}$ 184. The two peaks eluting late in the chromatogram contains the ladderane lipids $I-I V$ as shown in $\mathbf{b}$ and c. b Mass spectrum extracted from the peak at 12.5 min denoted $I I I, I V$ in a. The intact ladderane PC lipids $I I I$ and $I V$ at $m / z 814$ and 816 are identified. c Mass spectrum extracted from the peak at 16 min denoted $I, I I$ in A. The intact ladderane PC lipids $I$ and $I I$ at $\mathrm{m} / \mathrm{z} 800$ and 802 are identified. d Selected mass chromatogram for the intact ladderane PC lipid IV at $\mathrm{m} / \mathrm{z} 816$ in a sediment sample analyzed by RP-LC QToF scanning between $\mathrm{m} / \mathrm{z} 100$ and 900 . e Mass spectrum extracted from the peak at 16 min denoted $I V$ in $\mathbf{d}$. The intact ladderane PC lipids $I I I$ and $I V$ at $\mathrm{m} /$ $z 814$ and 816 are identified the west coast of Sweden. As can be seen in the mass spectra from both biofilm and sediment samples the RP-LC method clearly separate the ladderane PC lipids from other lipid species in the complex sediment sample.
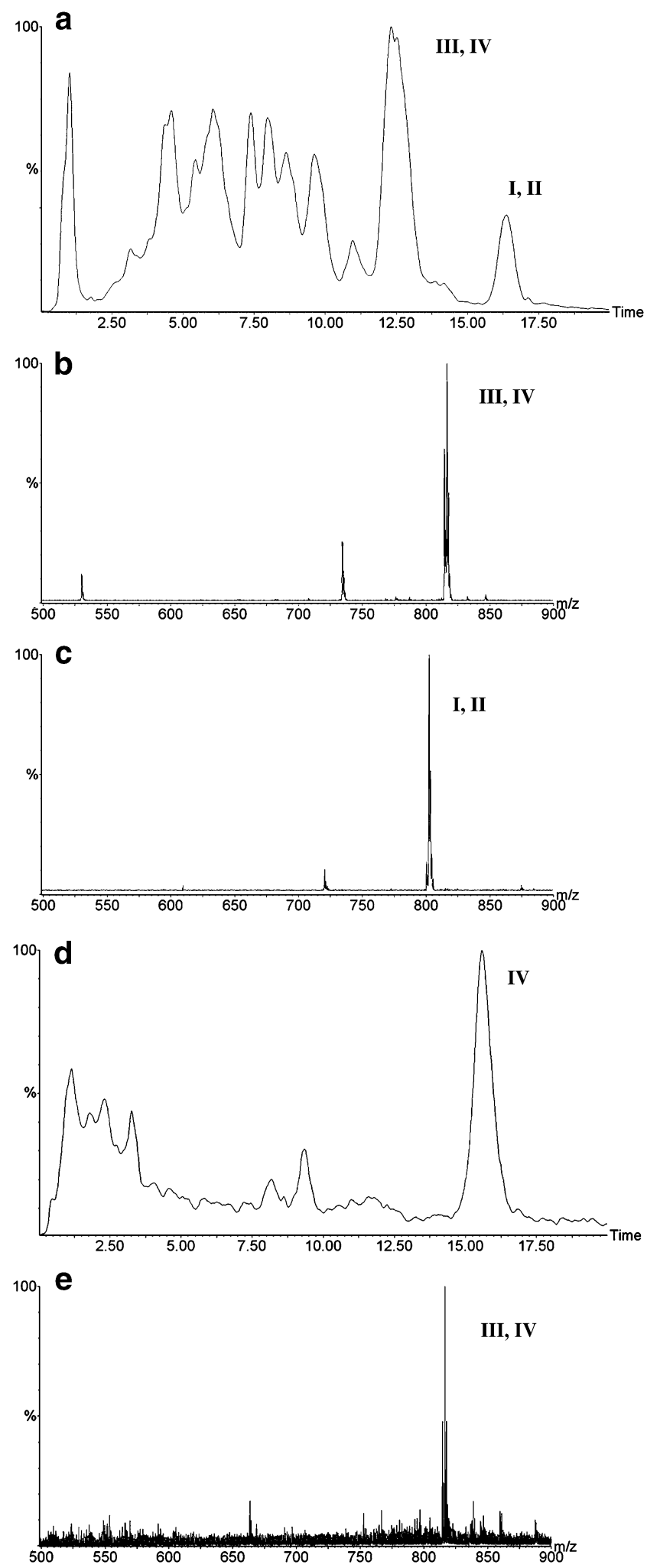
Determination of a specific ladderane biomarker

The ladderane PC lipid at $\mathrm{m} / \mathrm{z} 816$ was chosen as a biomarker for anammox bacteria based on two important characteristics. First; the ladderane PC lipid at $\mathrm{m} / \mathrm{z} 816$ displays the highest abundance in the mass spectrum when using the described method. Second, the ladderane PC lipid at $m / z 816$ is an ether-ester-linked ladderane lipid, which we have observed to be less stable in sediment when compared to the ether-ether linked PC lipids. The low stability in sediment environment also suggests that this lipid would better track living anammox bacteria. This was investigated by analyzing the amount of ester-ether (e.g., $\mathrm{m} / \mathrm{z}$ 816) and ether-ether (e.g., $\mathrm{m} / \mathrm{z} 800$ ) linked ladderane PC lipids in fresh sediment and again after storing that same sediment for more than 1 month in a refrigerator and at $-20{ }^{\circ} \mathrm{C}$. The ether-ester ladderane PC lipids were found in reduced levels in the older sediments compared to the fresh, whereas the ether-ether ladderane PC lipids were found in the same amounts regardless of sediment type. This observation suggests that the degradation in sediment for these lipids does not occur at similar rates and that an ester-ether linked ladderane PC lipid is a suitable biomarker for living anammox bacteria. Furthermore, the stability of the ether-ether ladderane PC lipids offers an explanation to why other studies, analyzing ladderane lipid degradation products, have found ladderane FAs and ladderane lysolipids spread throughout the sediment depth profiles [33].

To demonstrate the accuracy of the ladderane PC lipid at $\mathrm{m} / \mathrm{z} 816$ as biomarker for viable anammox bacteria we have performed tests on both samples from the waste water treatment plant Himmerfjärdsverket in Stockholm, Sweden and a sediment core from Gullmarsfjorden on the west coast of Sweden. Biofilm samples from three of the reactors at Himmerfjärdsverket presumably containing anammox bacteria were analyzed. The biomarker was present in the sample from the reactor that displayed anammox activity (data not shown), shown by the generation of nitrogen gas under anoxic conditions, indicating the presence of intact living anammox bacteria in the reactor.

Detecting ladderane PC lipids in the complex matrix of sediment is considerably more difficult. The corresponding mass chromatograms of $m / z 816$ at the depths $0-3,3-6$, 6-9, and 9-12 cm are shown in Fig. 5a. Nutrient and oxygen profiles, previously investigated by, e.g., Jaeschke et al. [33], indicates that anammox bacteria reside in the upper layer of the sediment, close to the border between the anoxic and oxic zone. Accordingly, the ladderane PC lipid biomarker at $\mathrm{m} / \mathrm{z} 816$ was found at this depth, as shown in the depth profile in Fig. 5b. The more stable ether-ether ladderane PC lipid at $\mathrm{m} / \mathrm{z} 800$ was, however, found at almost every depth in the core, likely due to the slower degradation rate for ether-ether PC lipids relative to the ether-ester lipids, as discussed above. The amount of ladderane PC lipids found at these depths can be related to each other since the ladderane PC lipids have a linear response (integrated peak area versus concentration) in the concentration range of interest (data not shown). In this, example the depths in the core are rough, and the depth at which the anammox bacteria are focused is probably a lot
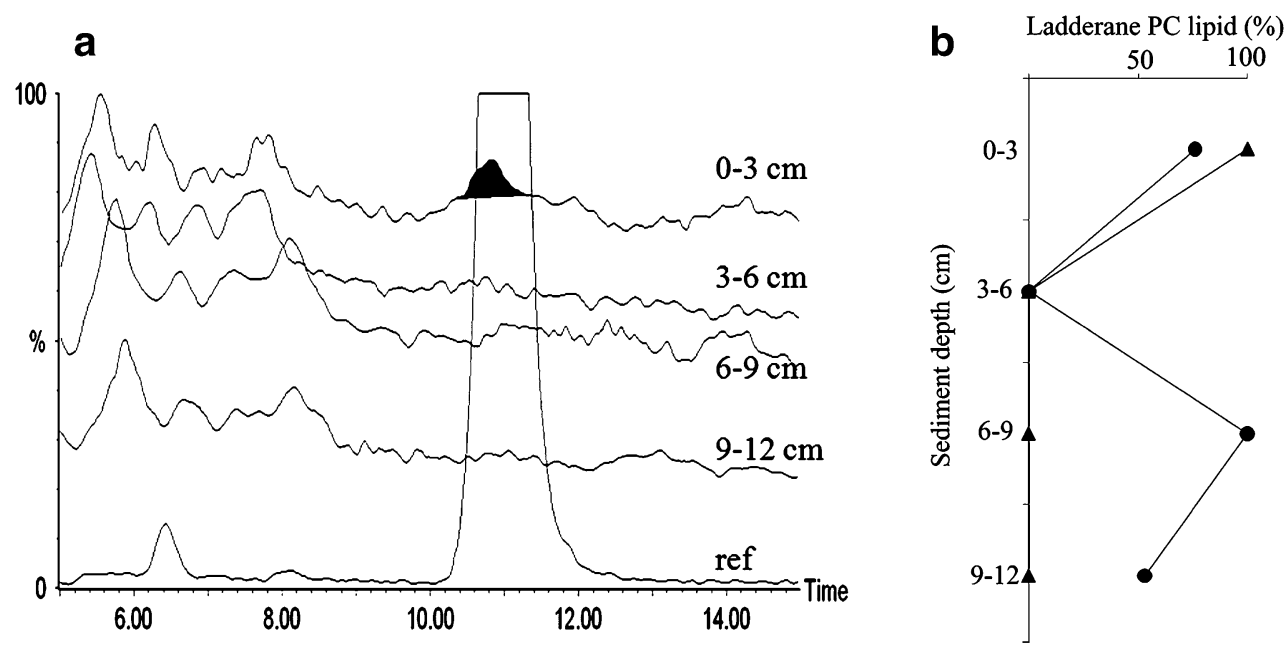

Fig. 5 Result from the sediment depth profile study. a Four overlayed mass chromatograms of $m / z$ 816. The sediment sample depths are indicated at the traces. The bottom trace is a reference sample from a biofilm containing ladderane PC lipids. b Depth profile of ladderane PC lipid IV at $m / z 816$ (ether-ester), indicated by the triangles, and ladderane PC lipid I at $\mathrm{m} / \mathrm{z} 800$ (ether-ether), indicated by the circles.
Depth slices are $3 \mathrm{~cm}$ thick. For ladderane PC lipid IV, at $m / z$ 816, the peaks were normalized to the maximum area found at depth $0-3 \mathrm{~cm}$ denoted $100 \%$. For ladderane PC lipid I, at $\mathrm{m} / \mathrm{z} 800$, the peaks were normalized to the maximum area found at depth $6-9 \mathrm{~cm}$ denoted $100 \%$ 
narrower. The finding of anammox bacteria at this site in Gullmarsfjorden is consistent with previous observations $[4,50]$.

\section{Conclusions}

A method has been developed to analyze intact ladderane PC lipids using RP-LC-ESI-MS. In this study, the method was used to identify a specific intact ladderane PC lipid biomarker for viable anammox bacteria. The chosen biomarker is an ether-ester ladderane PC lipid which is found at $\mathrm{m} / \mathrm{z}$ 816. Further, three different methods for extracting ladderane PC lipids have been evaluated and a multistep sample clean up procedure for ladderane lipids in sediment samples is described. When using the described method on sediment samples, we found that the selected biomarker is present only in the upper part of the sediment core. This finding is supported by earlier observations that anammox bacteria resides in the upper part of the sediment, just below the oxic zone. The described method provides a new tool for the anammox-interested research community to study viable anammox bacteria in natural environments. This will lead to an increased understanding of the preferred biogeochemical environment of the anammox bacteria and how their community structure is affected by ongoing environmental changes. Furthermore, the localization of viable anammox bacteria and a concomitant observation of anammox activity will contribute to a greater understanding of the global nitrogen cycle.

Acknowledgments The authors would like to greatly acknowledge Professor Stefan Hulth and his group at the Department of Chemistry, University of Gothenburg for fruitful discussions as well as help with sample collection.

Open Access This article is distributed under the terms of the Creative Commons Attribution Noncommercial License which permits any noncommercial use, distribution, and reproduction in any medium, provided the original author(s) and source are credited.

\section{References}

1. Devol AH (2003) Nitrogen cycle - solution to a marine mystery. Nature 422:575-576

2. Kuypers MMM, Lavik G, Woebken D, Schmid M, Fuchs BM, Amann R, Jorgensen BB, Jetten MSM (2005) Massive nitrogen loss from the Benguela upwelling system through anaerobic ammonium oxidation. Proc Natl Acad Sci USA 102:6478-6483

3. Jaeschke A, den Camp H, Harhangi H, Klimiuk A, Hopmans EC, Jetten MSM, Schouten S, Damste JSS (2009) 16S rRNA gene and lipid biomarker evidence for anaerobic ammonium-oxidizing bacteria (anammox) in California and Nevada hot springs. FEMS Microbiol Ecol 67:343-350
4. Schmid MC, Risgaard-Petersen N, van de Vossenberg J, Kuypers MMM, Lavik G, Petersen J, Hulth S, Thamdrup B, Canfield D, Dalsgaard T, Rysgaard S, Sejr MK, Strous M, den Camp H, Jetten MSM (2007) Anaerobic ammonium-oxidizing bacteria in marine environments: widespread occurrence but low diversity. Environ Microbiol 9:1476-1484

5. Strous M, Fuerst JA, Kramer EHM, Logemann S, Muyzer G, van de Pas-Schoonen KT, Webb R, Kuenen JG, Jetten MSM (1999) Missing lithotroph identified as new planctomycete. Nature 400:446-449

6. Kuypers MMM, Sliekers AO, Lavik G, Schmid M, Jorgensen BB, Kuenen JG, Damste JSS, Strous M, Jetten MSM (2003) Anaerobic ammonium oxidation by anammox bacteria in the Black Sea. Nature 422:608-611

7. Schmid MC, Maas B, Dapena A, de Pas-Schoonen KV, de Vossenberg JV, Kartal B, van Niftrik L, Schmidt I, Cirpus I, Kuenen JG, Wagner M, Damste JSS, Kuypers M, Revsbech NP, Mendez R, Jetten MSM, Strous M (2005) Biomarkers for in situ detection of anaerobic ammonium-oxidizing (anammox) bacteria. Appl Environ Microbiol 71:1677-1684

8. Kuenen JG (2008) Anammox bacteria: from discovery to application. Nat Rev Microbiol 6:320-326

9. Thamdrup B, Dalsgaard T (2002) Production of N-2 through anaerobic ammonium oxidation coupled to nitrate reduction in marine sediments. Appl Environ Microbiol 68:1312-1318

10. Waki M, Yasuda T, Suzuki K, Sakai T, Suzuki N, Suzuki R, Matsuba K, Yokoyama H, Ogino A, Tanaka Y, Ueda S, Takeuchi M, Yamagishi T, Suwa Y (2010) Rate determination and distribution of anammox activity in activated sludge treating swine wastewater. Bioresource Technology 101:2685-2690

11. Dalsgaard T, Thamdrup B, Canfield DE (2005) Anaerobic ammonium oxidation (anammox) in the marine environment. Res Microbiol 156:457-464

12. Dalsgaard T, Canfield DE, Petersen J, Thamdrup B, Acuna-Gonzalez $\mathrm{J}$ (2003) N-2 production by the anammox reaction in the anoxic water column of Golfo Dulce, Costa Rica. Nature 422:606-608

13. Schubert CJ, Durisch-Kaiser E, Wehrli B, Thamdrup B, Lam P, Kuypers MMM (2006) Anaerobic ammonium oxidation in a tropical freshwater system (Lake Tanganyika). Environ Microbiol 8:1857-1863

14. Trimmer M, Nicholls JC, Deflandre B (2003) Anaerobic ammonium oxidation measured in sediments along the Thames estuary, United Kingdom. Appl Environ Microbiol 69:6447-6454

15. Rysgaard S, Glud RN (2004) Anaerobic N-2 production in Arctic sea ice. Limnol Oceanogr 49:86-94

16. Rysgaard S, Glud RN, Risgaard-Petersen N, Dalsgaard T (2004) Denitrification and anammox activity in Arctic marine sediments. Limnol Oceanogr 49:1493-1502

17. Hulth S, Aller RC, Gilbert F (1999) Coupled anoxic nitrification manganese reduction in marine sediments. Geochim Cosmochim Acta 63:49-66

18. Rich JJ, Dale OR, Song B, Ward BB (2008) Anaerobic ammonium oxidation (Anammox) in Chesapeake Bay sediments. Microb Ecol 55:311-320

19. Dale OR, Tobias CR, Song BK (2009) Biogeographical distribution of diverse anaerobic ammonium oxidizing (anammox) bacteria in Cape Fear River Estuary. Environ Microbiol 11:1194-1207

20. Nannipieri P, Ciardi C, Badalucco L, Casella S (1986) A method to determine soil DNA and RNA. Soil Biol Biochem 18:275-281

21. Schmid M, Twachtmann U, Klein M, Strous M, Juretschko S, Jetten M, Metzger JW, Schleifer KH, Wagner M (2000) Molecular evidence for genus level diversity of bacteria capable of catalyzing anaerobic ammonium oxidation. Syst Appl Microbiol 23:93-106

22. Coolen MJL, Overmann J (1998) Analysis of subfossil molecular remains of purple sulfur bacteria in a lake sediment. Appl Environ Microbiol 64:4513-4521 
23. Coolen MJL, Muyzer G, Rijpstra WIC, Schouten S, Volkman JK, Damste JSS (2004) Combined DNA and lipid analyses of sediments reveal changes in Holocene haptophyte and diatom populations in an Antarctic lake. Earth Planet Sci Lett 223:225-239

24. Byrne N, Strous M, Crepeau V, Kartal B, Birrien JL, Schmid M, Lesongeur F, Schouten S, Jaeschke A, Jetten M, Prieur D, Godfroy A (2009) Presence and activity of anaerobic ammonium-oxidizing bacteria at deep-sea hydrothermal vents. ISME J 3:117-123

25. Jetten MSM, van Niftrik L, Strous M, Kartal B, Keltjens JT, Op den Camp HJM (2009) Biochemistry and molecular biology of anammox bacteria. Crit Rev Biochem Mol Biol 44:65-84

26. Boumann HA, Hopmans EC, van de Leemput I, Op den Camp HJM, van de Vossenberg J, Strous M, Jetten MSM, Damste JSS, Schouten S (2006) Ladderane phospholipids in anammox bacteria comprise phosphocholine and phosphoethanolamine headgroups. FEMS Microbiol Lett 258:297-304

27. Rattray JE, van de Vossenberg J, Hopmans EC, Kartal B, van Niftrik L, Rijpstra WIC, Strous M, Jetten MSM, Schouten S, Damste JSS (2008) Ladderane lipid distribution in four genera of anammox bacteria. Arch Microbiol 190:51-66

28. Boumann HA, Longo ML, Stroeve P, Poolman B, Hopmans EC, Stuart MCA, Damste JSS, Schouten S (2009) Biophysical properties of membrane lipids of anammox bacteria: I. Ladderane phospholipids form highly organized fluid membranes. Biochim Biophys Acta Biomembr 1788:1444-1451

29. Sinninghe-Damsté JSS, Strous M, Rijpstra WIC, Hopmans EC, Geenevasen JAJ, van Duin ACT, van Niftrik LA, Jetten MSM (2002) Linearly concatenated cyclobutane lipids form a dense bacterial membrane. Nature 419:708-712

30. Sinninghe-Damsté JSS, Rijpstra WIC, Geenevasen JAJ, Strous M, Jetten MSM (2005) Structural identification of ladderane and other membrane lipids of planctomycetes capable of anaerobic ammonium oxidation (anammox). FEBS J 272:4270-4283

31. Jaeschke A, Lewan MD, Hopmans EC, Schouten S, Damste JSS (2008) Thermal stability of ladderane lipids as determined by hydrous pyrolysis. Org Geochem 39:1735-1741

32. Hopmans EC, Kienhuis MVM, Rattray JE, Jaeschke A, Schouten S, Damste JSS (2006) Improved analysis of ladderane lipids in biomass and sediments using high-performance liquid chromatography/atmospheric pressure chemical ionization tandem mass spectrometry. Rapid Commun Mass Spectrom 20:2099-2103

33. Jaeschke A, Rooks C, Trimmer M, Nicholls JC, Hopmans EC, Schouten S, Damste JSS (2009) Comparison of ladderane phospholipid and core lipids as indicators for anaerobic ammonium oxidation (anammox) in marine sediments. Geochim Cosmochim Acta 73:2077-2088

34. Aries E, Doumenq P, Artaud J, Molinet J, Bertrand JC (2001) Occurrence of fatty acids linked to non-phospholipid compounds in the polar fraction of a marine sedimentary extract from Carteau cove, France. Org Geochem 32:193-197

35. Sturt HF, Summons RE, Smith K, Elvert M, Hinrichs KU (2004) Intact polar membrane lipids in prokaryotes and sediments deciphered by high-performance liquid chromatography/electrospray ionization multistage mass spectrometry-new biomarkers for biogeochemistry and microbial ecology. Rapid Commun Mass Spectrom 18:617-628

36. Zink KG, Wilkes H, Disko U, Elvert M, Horsfield B (2003) Intact phospholipids - microbial "life markers" in marine deep subsurface sediments. Org Geochem 34:755-769

37. Mazzella N, Molinet J, Syakti AD, Bertrand JC, Doumenq P (2007) Assessment of the effects of hydrocarbon contamination on the sedimentary bacterial communities and determination of the polar lipid fraction purity: relevance of intact phospholipid analysis. Mar Chem 103:304-317

38. H. Ruetters, H. Sass, H. Cypionka, J. Rullkotter, in 4th International Symposium on the Interface between Analytical Chemistry and Microbiology, Bretagne, France, 2000, pp. 149-160

39. Zink KG, Mangelsdorf K, Granina L, Horsfield B (2008) Estimation of bacterial biomass in subsurface sediments by quantifying intact membrane phospholipids. Anal Bioanal Chem 390:885-896

40. Ruetters H, Sass H, Cypionka H, Rullkotter J (2002) Microbial communities in a Wadden Sea sediment core-clues from analyses of intact glyceride lipids, and released fatty acids. Org Geochem 33:803-816

41. Zink KG, Mangelsdorf K (2004) Efficient and rapid method for extraction of intact phospholipids from sediments combined with molecular structure elucidation using LC-ESI-MS-MS analysis. Anal Bioanal Chem 380:798-812

42. Folch J, Lees M, Stanley GHS (1957) A simple method for the isolation and purification of total lipids from animal tissues. J Biol Chem 226:497-509

43. Hara A, Radin NS (1978) Lipid extraction of tissues with a lowtoxicity solvent. Anal Biochem 90:420-426

44. Kaluzny MA, Duncan LA, Merritt MV, Epps DE (1985) Rapid separation of lipid classes in high-yield and purity using bonded phase columns. J Lipid Res 26:135-140

45. Huebner J, Wang Y, Krueger WA, Madoff LC, Martirosian G, Boisot S, Goldmann DA, Kasper DL, Tzianabos AO, Pier GB (1999) Isolation and chemical characterization of a capsular polysaccharide antigen shared by clinical isolates of Enterococcus faecalis and vancomycin-resistant Enterococcus faecium. Infect Immun 67:1213-1219

46. Liu CH, Lee SM, VanLare JM, Kasper DL, Mazmanian SK (2008) Regulation of surface architecture by symbiotic bacteria mediates host colonization. Proc Natl Acad Sci USA 105:3951-3956

47. Elvers KT, Leeming K, Moore CP, Lappin-Scott HM (1998) Bacterial-fungal biofilms in flowing water photo-processing tanks. J Appl Microbiol 84:607-618

48. O'Toole G, Kaplan HB, Kolter R (2000) Biofilm formation as microbial development. Annu Rev Microbiol 54:49-79

49. Al-Saad KA, Siems WF, Hill HH, Zabrouskov V, Knowles NR (2003) Structural analysis of phosphatidylcholines by post-source decay matrix-assisted laser desorption/ionization time-of-flight mass spectrometry. J Am Soc Mass Spectrom 14:373-382

50. van de Vossenberg J, Rattray JE, Geerts W, Kartal B, van Niftrik L, van Donselaar EG, Damste JSS, Strous M, Jetten MSM (2008) Enrichment and characterization of marine anammox bacteria associated with global nitrogen gas production. Environ Microbiol $10: 3120-3129$ 